\title{
Methods of lymphoedema reduction presented in view of literature - systematic review
}

\section{Metody redukcji obrzęku limfatycznego na podstawie piśmiennictwa - przegląd systematyczny}

\author{
Paweł Macek ${ }^{1,2}$, Małgorzata Terek¹, Stanisław Z. Głuszek ${ }^{3,4}$, Michał Motyka1 , Stanisław Góźdź1,4 \\ ${ }^{1}$ Oncology Clinic, Holy Cross Cancer Centre, Kielce, Poland \\ Head of the Clinic: Stanisław Góźdź MD, PhD \\ ${ }^{2}$ Medical College-Department of Health Sciences, The Higher School of Economy, Law and Medical Sciences, Kielce, Poland \\ Head of the Department: Grzegorz Gałuszka MD, PhD \\ ${ }^{3}$ General Surgery, Oncology and Endocrinology Clinic, Provincial Hospital, Kielce, Poland \\ Head of the Clinic: Prof. Stanisław Głuszek MD, PhD \\ ${ }^{4}$ Department of Health Sciences, Jan Kochanowski University, Kielce, Poland \\ Head of the Department: Prof. Stanisław Głuszek MD, PhD
}

Key words: lymphoedema, breast cancer, systematic review.

Słowa kluczowe: obrzęk limfatyczny, rak piersi, przegląd systematyczny.

\begin{abstract}
Lymphoedema (LE) is a serious oncological complication of breast cancer treatment. Untreated, it leads to several changes in the upper limbs of patients, including limiting the mobility of joints and functions. Schematic complete decongestive therapy (CDT) is one of the most common methods of conservative treatment of LE. Complete decongestive therapy regimen is also often used as monotherapy for selected items, such as: manual lymphatic drainage, compression therapy and exercises for improvement. This study is a systematic review of scientific publications on the reduction of the lymphoedemas associated with breast cancer (BCRL). The aim of the research study was to present of the methods used to reduce LE associated with breast cancer. All the analysed papers were selected from Medline after ticking the following options: publication type - clinical trail; availability of text - free full text available; published - in the last 5 years. For final analysis, 9 (6 randomised and 3 non-randomised) studies were chosen out of the 1,392 records showing different methods of conservative treatment of BCRL. Based on the available literature, the greatest reduction in LE was obtained using different methods of conservative treatment. Of note are the studies which evaluate the effectiveness of new methods that are not part of the commonly used CDT scheme in practice. The education strategy generally supports such methods.
\end{abstract}

\section{Streszczenie}

Obrzęk limfatyczny (lymphoedema - LE) jest jednym z najpoważniejszych powikłań onkologicznego leczenia raka piersi. Nieleczony prowadzi do licznych zmian w obrębie kończyny górnej, m.in. ograniczenia ruchomości w stawach i zaburzenia funkcji kończyny. Jedną z najczęściej stosowanych metod leczenia zachowawczego LE jest schemat CDT (complete decongestive therapy). Podobnie często w monoterapii stosowane są wybrane elementy schematu CDT w postaci: manualnego drenażu limfatycznego, kompresjoterapii i ćwiczeń usprawniających. Praca jest systematycznym przeglądem publikacji naukowych dotyczących metod redukcji LE związanego z rakiem piersi. Na podstawie dostępnego piśmiennictwa stwierdzono największą redukcję LE w przypadku łączenia różnych metod leczenia zachowawczego. Uwagę zwracają badania oceniające skuteczność nowych metod niebędących częścią powszechnie stosowanego w praktyce schematu CDT. Metody te najczęściej wspierane są strategią edukacyjną.

\section{Introduction}

Lymphoedema (LE) is one of the most serious complications of oncological treatment of breast cancer [1]. It is produced by the accumulation of protein substances in intra tissue spaces [2]. Excess protein substances remaining in the extracellular space lead to the growth of adipose tissue and fibrosis of connec- tive tissue [3]. Increasing limb circuits affected LE the restricted mobility of the joints and impair its function [4]. Breast cancer-related lymphedema (BCRL) chronic complication is a result of the development of secondary cancers of the upper limb [5]. Lymphoedema diagnosis is based on clinical examination and analysis of medical records [6]. The most commonly 
used methods of assessing the size of LE are anthropometric measurement of circuits or of the volume of the upper limb. Non-invasive methods for the diagnosis of LE also include bioimpedance method, tonometry and perometry [7-9].

In cases where the clinical observation does not provide enough data for a correct diagnosis, methods of radiological imaging of tissue may be used (computed tomography - CT, magnetic resonance imaging - MRI and lymphoscintigraphy) [10-12]. A commonly used algorithm for LE conservative treatment is complete decongestive therapy (CDT) regimen [13]. Assumptions about the applicability of the treatment regimen CDT for LE have been scientifically verified to confirm their efficacy [14]. The CDT scheme consists of four elements: manual lymphatic drainage (MLD), compression therapy, skin care and exercises for improvement [13]. In order to maintain the effects of the CDT scheme after its completion, the patient should be provided with a compression sleeve. The sleeve is used frequently during the day and is removable for comfort during sleeping [4].

\section{Aim of the research study}

The aim of the study is the presentation of the methods used to reduce the LE associated with breast cancer.

\section{Material and methods}

A literature review was performed using the Medline database by entering the following keywords and phrases: BCRL, BCRL and maintenance, MLD, lymphoedema and arm swelling, lymphoedema exercises, and lymphoedema and compression therapy. All potentially significant records and abstracts of articles were analysed. Only the scientific publications listed in Medline that appeared after ticking the following choices were qualified for analysis: publication type - clinical trial; availability of text - free full text available; published - in the last 5 years.

\section{Review of the literature}

After entering the keywords, 1392 scientific publications appeared, of which only 18 met all of the inclusion criteria. Three of them were research projects, one referred to rehabilitation of the shoulder joint in women with BCRL, two described methods of surgical resection of involved axillary lymph nodes, two focused on the efficacy of electroacupuncture and acupuncture in the treatment of joint pain in women with breast cancer (BC), and the last one concerned the risk of osteoarthritis in women at risk of BCRL. The final analysis was based on the 9 scientific papers. Six of them were randomised clinical trials and three were non-randomised clinical trials.
Torres Lacombe et al. [15], in a randomised, single-blind control study, observed 120 women with unilateral mastectomy with axillary dissection. The women were divided into two equal groups. The study group (early physiotherapy group - EPG) received MLD, scar massage, exercise of the shoulder and education strategy (information about the lymphatic system, the concept of normal load and overload as a source of lymphoedema, information on risk factors for oedema, and the four categories of oedema prevention: avoidance of trauma, avoidance of injury, infection prevention, avoidance of oppression of limbs. The control group (CG) received only the education strategy. Lymphoedema in the EPG group was evaluated based on metric measurement by tape measure of the circuits of both upper limbs. The measurements were performed in 5-centimetre intervals along the entire limb. An increase in the circumference of the limb by approximately $2 \mathrm{~cm}$ or more as compared to the healthy limb was considered as LE. The volume of the limbs were calculated based on the formula for the volume of the truncated cone using measurements of circuits of the limbs. The measurements were performed during each visit. The observation was conducted for 12 months. One hundred and sixteen out of 120 women completed the study (59 in the EPG group and 57 in the CG group). Lymphoedema occurred in $14(7 \%)$ women in the CG and in $4(7 \%)$ women in the EPG $(p=0.01)$ with the existence of similar risk factors. After 12 months of follow-up, the limb volume ratio increased by $5.1 \%$ in the CG and by $1.6 \%$ in the EPG ( $p=0.0065)$. The maximum difference between two adjacent measuring points was also higher in the CG than in the EPG $(1.15 \mathrm{~cm}$ vs. $0.68 \mathrm{~cm}, p=0.0207)$. Lymphoedema was performed four times faster in the CG than in the EPG (EPG/CG, hazard ratio $0.26,95 \%$ CI $0.09-0.79, p=0.010)$.

Fife et al. [16], in a randomised prospective study conducted in a group of 35 patients with BCRL, compared two types of pneumatic compression used in LE therapy. Applied interventions, SPCD (Bio Compression 2004, Sequential Circulator, PCD) and APCD (Flexitouch system, Tactile Systems Technology) were conducted in two equal groups $(\mathrm{APCD}=18 \mathrm{vs}$. SPCD $=18$ ) as a form of home maintenance therapy. The study included women with a minimum of 18 years with confirmed diagnosis of LE after treatment with BC, who completed an intensive phase of therapy stent (phase I) and had been directed to maintenance treatment (phase II) with 5\% difference in the volume of the upper limbs. The measurement circuits of limbs were performed with the help of a Gulick metric tape. On the basis of the results, the volume of the limbs were calculated using the formula for the volume of a truncated cone. Changes in volume of LE in all patients were evaluated before initiation of therapy and after 12 weeks of treatment at home. In 
addition, in the group of 28 patients $(\mathrm{APCD}=14 \mathrm{vs}$. $\mathrm{SPCD}=14$ ) the extracellular water content of the limb was also evaluated using the method of tissue dielectric constant (TDC). Based on the results of Fife et al. we found no differences in the size of LE in the study groups at baseline (APCD $=18$ vs. SPCD $=18)$. After 12 weeks of treatment a significant change $(p=0.018)$ in group size LE was seen (APCD 118, SD = $170 \mathrm{ml}$ and SPCD $6.3, \mathrm{SD}=216 \mathrm{ml}$ ). The results of the study also showed a significant change $(p=0.05)$ in the extracellular water content evaluated by TDC method (APCD $3.1, \mathrm{SD}=4.9$ and $\mathrm{SPCD} 0.4, \mathrm{SD}=3.9)$. Any reduction in the size of LE was marked as (-) by the authors of this study.

De Fatima Guerreiro Godoy et al. [17] in a randomised clinical study, observed 20 women aged from 49 to 82 years (mean age 63.3 years) with BCRL. The volume was measured in both upper limbs using a tank filled with water. Lymphoedema was defined as a difference in volume between the sick and the healthy upper limb greater than or equal to $200 \mathrm{ml}$. Subjects performed two sessions of active exercises, one with compression garments, the other without. Each training session consisted of a total of $12 \mathrm{~min}$ activity (four 3-minute intervals). The measurements were performed before and at the end of each session. De Fatima Guerreiro Godoy et al. observed a significant reduction ( $p=0.0004)$ in upper limb volume of $24.6 \mathrm{ml}(\mathrm{SD}=25.6 \mathrm{ml})$ during practice sessions of active compression garments. There was also an average increase in limb volume of $9.7 \mathrm{ml}(\mathrm{SD}=33.3 \mathrm{ml})$ in patients performing active exercises without compression garments, although this was not statistically significant $(p=0.2)$. In conclusion, the authors ofthe study indicate the need foractive exercises in compression garments for patients suffering from BCRL.

Belmonte et al. [18], in a randomised, single-blind crossover study, observed 36 women with BCRL. All patients underwent intensive phase (phase I) CDT and started the year before the maintenance phase (phase II). Allocation to one of two groups (group A: $n=19$, group B: $n=17$ ) was based on a randomisation list generated by a computer program. The MLD and electrotherapy treatment of low frequency and low intensity (ET) was used in group A. In group B, ET was applied followed by MLD. The ET was performed with wave carrier frequency from $0.31 \mathrm{~Hz}$ to $6.16 \mathrm{~Hz}$ and modulation between $400 \mathrm{~Hz}$ and $2120 \mathrm{~Hz}$. Low offset voltage ranged between $+12 \mathrm{~V}$ and $-12 \mathrm{~V}$. The duration of the procedure was $50 \mathrm{~min}$. The MLD treatment was performed in a standard manner. The ET and MLD were administered to all patients once daily for 10 days. The size of LE was calculated as the difference in volume between the healthy limb and the non-healthy limb. Limb volume was calculated using the formula for the volume of the truncated cone using measurements taken from the limbs circuit on
6 levels. The LE was classified as light $<20 \%$, moderate $20-40 \%$, or severe $>40 \%$. The measurements were performed before each treatment session. Base on the results, Belmonte et al. found no significant reduction in LE before and after ET ( $p=0.36)$. The authors have, however, pointed to a significant reduction of pain after applied ET $(p=0.05)$.

Bordin et al. [19] studied a group of 25 patients with BCRL. The ages of the women ranged from 42 to 86 years. The patients were qualified for the study according to the order of arrival at the Lymphedema Treatment Centre, and after obtaining their informed consent. Lymphoedema was identified on the basis of the results of lymphoscintigraphy and measurement of the volume of the upper limbs using a tank of water. Lymphoedema was classified as a limb volume difference greater than or equal to $200 \mathrm{ml}$. All patients underwent a 1-hour practice session with a RAGodoy ${ }^{\circledR}$ mechanical device which involved bending the limb at the elbow and stretching exercises. Measurement of the limb was performed before and after each exercise session. On the basis of these results, Bordin et al. stated that reduction in volume of the limb was significant $(p<$ 0.0001 ) in 23 patients (average initial volume was 2026.4 $\mathrm{ml}$, the average final volume was $1967.2 \mathrm{ml}$, so mean volume reduction was $59.2 \mathrm{ml}$ ). An increase in the volume of the diseased upper limb occurred only in two cases.

Devoogdt et al. [20], in a randomised clinical trial, observed 160 women with BCRL after mastectomy and axillary lymph node dissection. Of the 160 patients in the trial, 79 women were assigned to the intervention group (IG) and 81 were assigned to the CG. In both groups the volume of circuits of the upper limbs were measured using a tank of water. In the IG, a treatment program was used consisting of information on the prevention of LE, physical exercises and MLD. In the CG, the oedema-reducing prophylaxis and physical exercises were applied. Information concerning prevention and exercises, were given to the patients after surgery. The MLD was used 1 week after the surgery for a period of 20 weeks. Oedema-reducing prevention involved the following: lifting the upper limb during the appearance of a feeling of heaviness, avoidance of lifting heavy objects, avoidance of repetitive movements, avoidance of extreme temperatures, the principles of limbcare, wearing a compression sleeve during air travel, and avoidance of weight gain. The physical exercises lasted for $30 \mathrm{~min}$. Initially, sessions were held once a week, then 3 times a week and in the final period once one every 2 weeks, in order to adapt the lymphatic system to work independently. One year after surgery the LE presence in both groups was comparable (IG 24\%, CG 19\%, hazard ratio 1.3, 95\% PU 0.6-2.9, $p=0.45$ ).

Schmitz et al. [21], in a randomised control study, evaluated the impact of weightlifting on LE in 140 women with BCRL. The LE was defined, using the Com- 
mon Toxicity Criteria, as a 10\% or greater difference in circuit between the diseased and healthy upper limbs. Patients were assigned to two equinumerous groups (1:1). The end point was the change in extracellular water content in the affected upper limb LE measured by electrical bioimpedance method 12 months after the start of the study. After a year of observation, among the 140 examined patients, 5\% had an increase in LE. In the group who were lifting weights, this amounted to $11 \%$ and in the control group this was $12 \%$. Compared to the control group, the weight lifting group reported greater improvement in LE $(p=0.03)$. In contrast to the guidelines regarding avoidance of lifting using upper limbs with LE, they found that lifting weights did not significantly affect the severity of LE symptoms in women with BCRL.

Cassileth et al. [22] evaluated the safety and efficacy of acupuncture applied to the upper diseased limbs in women with BCRL. The study group consisted of 37 women with BCRL. Lymphoedema lasting from 0.5 to 5 years after surgery was classified, on the basis of anthropometric measurements, as a difference of upper limb circuit greater than or equal to $2 \mathrm{~cm}$. The study was based on the informed consent of the patients and the approval of a qualified oncologist for patient participation in the study. Selection criteria for the study group were age over 18 years, unilateral LE, difference of circuits of the upper limbs greater than or equal to $2 \mathrm{~cm}$, and LE diagnosed no less than 6 months ago and no more than 5 years ago. Treatment was carried out two times a week for 4 weeks. The duration of the procedure was $30 \mathrm{~min}$. Thirty-three patients out of the 37 completed the treatment. Four patients discontinued the study due to time constraints. Based on the results obtained by Cassileth et al., we found the average reduction in the difference of the upper limb circuits to be $0.90 \mathrm{~cm}(95 \%$ CI $0.72-1.07, p<0.0005)$. Eleven patients (33\%) showed 30\% reduction in LE after treatment with acupuncture. Of the 37 patients, $76 \%$ had used all acupuncture treatments (225 treatments), $21 \%$ did not use 1 treatment, 3\% had not used the 2 treatments. During the period of treatment, 12 of the 33 women had minor complaints in the form of mild bruising of the limbs, local pain or tingling. There were no serious adverse events, infections or severe exacerbations of LE after the 225 acupuncture sessions, or 6 months after the end of the study. Cassileth et al. concluded that acupuncture in patients with BCRL appears to be safe and can lead to reduced symptoms of LE.

Hou et al. [23] presented the short-and long-term effects of transplantation of bone marrow stromal cells (BMSC) in the treatment of LE in women with BCRL. The BMSC transplantation regimen was compared with CDT. A total of 50 women after mastectomy and/or radiotherapy were qualified to the study.
The intervention group (BMSC group) consisted of 15 patients who received transplanted BMSC. Bone marrow (50 ml 10,000 IU heparin) was taken from the iliac crest. Once prepared, mononuclear cells were administrated to the patient using general or local anaesthesia. Transplantation of cells concerned the armpit, the chest wall and part of the operated arm. The control group (CDT group) consisted of 35 patients, in which the CDT scheme was applied. Lymphoedema was classified on the basis of the volume difference of the diseased and healthy upper limbs of the patient. The volume of the limb was calculated based on anthropometric measurements and the model for the volume of a truncated cone. The measurements of extremity circuits were performed according to the Kurz model in 4-centimetre intervals starting from the wrist. Measurements of the limbs were made at the beginning of the study and then 1, 3 and 12 months later. In addition, all patients rated the pain of the diseased upper limb and/or chest using a numerical scale from 0 to 5 ( 0 - no pain, 5 - strong and constant pain). Before starting the treatment, the mean volume of LE in the BMSC group amounted to $1166.2 \mathrm{ml}$, and $1091.0 \mathrm{ml}$ in the CDT group. Average reduction of LE in BMSC group was $730.7 \mathrm{ml}, 887.9 \mathrm{ml}$ and $958.6 \mathrm{ml}$ and $714.8 \mathrm{ml}, 657.9 \mathrm{ml}$ and $571.3 \mathrm{ml}$ in the CDT group (respectively 1, 3 and 12 months) after completion of the treatment. Before starting the treatment, the percentage of LE in the BMSC group was $28.6 \%$, and $26.8 \%$ in the CDT group. The reduction of LE in the BMSC group was $64.6 \%, 78.5 \%$ and $81.0 \%$ and $67.2 \%$, $60.4 \%$ and $54.5 \%$ in the CDT group (respectively, at 1,3 and 12 months). At the start of the treatment, the average subjective evaluation of upper limb and/ or chestpain in the BMSC group was 3.4, and 4.0 in the CDT group. The mean subjective assessment of pain in the BMSC group was 1.6, 0.8 and 0.6 and 1.2, 1.7 and 1.6 in the CDT group (respectively, at 1, 3 and 12 months) after completion of the treatment.

\section{Summary}

The BCRL is a chronic disease that permanently damages the mental and physical sphere of patients. The search for effective methods of conservative treatment of LE is reflected in scientific publications investigating the effectiveness of various therapeutic procedures. Some authors have shown improvement in therapeutic response by using combination therapy (CDT). Others promote monotherapy (MLD). Still others look for innovative solutions such as acupuncture or transplantation of bone marrow stromal cells to stimulate vascular growth. Based on the available literature, the authors concluded that the greatest reduction in LE was obtained by matching different methods of conservative treatment. Noteworthy are those studies which evaluate the effectiveness of new methods that are not widely used in CDT practice reg- 
imen. These methods are generally supported by the education policy. Individual research reports showing the efficacy of acupuncture, electrotherapy or transplantation of BMSC do not change the existing rules of procedure in patients with BCRL. However, they show the insufficient efficiency of the CDT scheme and highlight the need to find new solutions for the treatment of LE.

\section{References}

1. Warren AG. Lymphedema a comprehensive review. Ann Plast Surg 2007; 59: 464-472.

2. Krukowska J, Terek M, Macek P, et al. Metody redukcji obrzęku limfatycznego $\mathrm{u}$ kobiet po mastektomii (The methods of treatment of lymphoedema in women after mastectomy). Fizjoterapia 2010; 18: 3-10.

3. Renkielska A, Grobelny I, Grudziński J, et al. Metoda skojarzonego leczenia obrzęku limfatycznego kończyny górnej u chorych po amputacji piersi z powodu raka (The method of combined treatment of upper extremity lymphedema in patients after mastectomy for cancer). Contemp Onkol 2003; 7: 777-786.

4. Macek P, Stanisławek A, Góźdź S. Obrzęk limfatyczny przegląd literatury (Limphoedema - literature review). Onkologia i Radioterapia 2010; 4: 24-31.

5. Głuszek S. Case of Stewart-Treves syndrome. Wiad Lek 1981; 34: 321-323.

6. Rockson GS. Lymphedema. Am J Med 2001; 110: 288-295.

7. Ward LC. Bioelectrical impedance analysis: proven utility in lymphedema risk assessment and therapeutic monitoring. Lymphat Res Biol 2006; 4: 51-56.

8. Bagheri S, Ohlin K, Olsson G, et al. Tissue tonometry before and after liposuction of arm lymphedema following breast cancer. Lymphat Res Biol 2005; 3: 66-80.

9. Moseley A, Piller N, Carati C. Combined opto-electronic perometry and bioimpedance to measure objectively the effectiveness of a new treatment intervention for chronic secondary leg lymphedema. Lymphology 2002; 35: 136-143.

10. McNeill GC, Witte MH, Witte CL, et al. Whole-body lymphangioscintigraphy: preferred method for initial assessment of the peripheral lymphatic system. Radiology 1989; 172: 495-502.

11. Monnin-Delhom ED, Gallix BP, Achard C, et al. High resolution unenhanced computed tomography in patients with swollen legs. Lymphology 2002; 35: 121-128.

12. Case TC, Witte CL, Witte MH, et al. Magnetic resonance imaging in human lymphedema: comparison with lymphangioscintigraphy. Magn Reson Imaging 1992; 10: 549-558.

13. Casley-Smith JR, Boris M, Weindorf S, et al. Treatment for lymphedema of the arm - the Casley-Smith method. Cancer 1998; 83: 2843-2860.

14. Foldi E. Comprehensive lymphedema treatment center. Lymphology 1994; 27: 505-507.

15. Torres Lacomba M, Yuste Sanchez MJ, Zapico Goni A, et al. Effectiveness of early physiotherapy to prevent lymphoedema after surgery for breast cancer: randomised, single blinded, clinical trial. BMJ 2010; 340: b5396-b5404.

16. Fife CE, Davey S, Maus EA, et al. A randomized controlled trial comparing two types of pneumatic compression for breast cancer-related lymphedema treatment in the home. Support Care Cancer 2012; 20: 3279-3286.
17. De Fatima Guerreiro Godoy M, Pereira MR, Heli Oliani A, et al. Synergic effect of compression therapy and controlled active exercises using a facilitating device in the treatment of arm lymphedema. Int J Med Sci 2012; 9: 280-284.

18. Belmonte R, Tejero M, Ferrer M, et al. Efficacy of low-frequency low-intensity electrotherapy in the treatment of breast cancer-related lymphoedema: a cross-over randomized trial. Clin Rehabil 2012; 26: 607-618.

19. Bordin NA, de Fatima Guerreiro Godoy M, Pereira de Godoy JM. Mechanical lymphatic drainage in the treatment of arm lymphedema. Indian J Cancer 2009; 46: 337-339.

20. Devoogdt N, Christiaens MR, Geraerts I, et al. Effect of manual lymph drainage in addition to guidelines and exercise therapy on arm lymphoedema related to breast cancer: randomised controlled trial. BMJ 2011; 343: 1-12.

21. Schmitz KH, Ahmed RL, Traxel A, et al. Weight lifting in women with breast cancer-related lymphedema. $\mathrm{N}$ Engl J Med 2009; 361: 664-673.

22. Cassileth BR, Van KJ, Yeung KS, et al. Acupuncture in the treatment of upper-limb lymphedema. Cancer 2013; 119: 2455-2461.

23. Hou $\mathrm{C}, \mathrm{Wu} \mathrm{X}$, Jin $\mathrm{X}$. Autologous bone arrow stromal cells transplantation for the treatment of secondary arm lymphedema: a prospective controlled study in patients with breast cancer related lymphedema. Jpn J Clin Oncol 2008; 38: 670-674.

\section{Address for correspondence:}

\section{Paweł Macek MD}

Oncology Clinic

ul. Artwińskiego 3, 25-734 Kielce, Poland

Phone: +48 603161576

E-mail: pawel.macek@gazeta.pl 